\title{
Agent Previous Occurrence
}

National Cancer Institute

\section{Source}

National Cancer Institute. Agent Previous Occurrence. NCI Thesaurus. Code C162325.

An indication or description that a particular agent administration event happened in the past. 